\title{
Disputes over Private Property Rights in Deir El-Madina
}

\author{
Hebatallah Sobhy Ibrahim Abdou \\ Faculty of Tourism and Hotel Management, Sadat City University
}

\begin{abstract}
The documentations found at both the village and the royal worksites of Deir elMadina has added a lot to our understanding of the various aspects of the Egyptian society. However, until now there have been limited studies of the human interrelation of the society of Deir el-Medina. The study focuses on the private property rights, as housing within the boundaries of the village which was provided for the workmen by the state. It has been suggested that upon a workman's attachment to the workforce he was given certain properties for his personal use. These buildings consisted of a house, a hut, a chapel, and a tomb, which belonged to the government. These were therefore not allowed to be freely sold or inherited. On this assumption it would be likely that upon the death of a workman, the freehold of these buildings would, in theory, revert back to the state to be assigned to his successor. But this state of affairs may not be strictly happening. This was discussed in details through the texts of different cases from the related sources.
\end{abstract}

\section{Introduction}

Housing within the boundaries of the village was provided for the workmen by the state. It has been suggested that upon a workman's attachment to the workforce, he was given certain properties for his personal use. These buildings consisted of a house (pr), a hut (at), a chapel (xnw) and a tomb (aHat), which belonged to the government and which were therefore not allowed to be sold or inherited. ${ }^{1}$ On this assumption it would be likely that upon the death of a workman, the freehold of these buildings would, in hypothesis, revert back to the state to be allocated to his successor. ${ }^{2}$ Nevertheless this state of relationships may not be strictly happening when consideration is given to the events described in Pap. Bulaq X. Here Hay, son of Huy, is documented leaving two separate at-huts to his children. However it is possible to argue that these at-huts were actually privately built constructions for use by the workmen and their families, and are therefore to be differentiated from the at-huts found at the royal worksites. In fact one of them appears to have been situated close to the village "beside the xnw of Huy". ${ }^{3}$ Similarly the xnw which the draftsman Rehotep sold to Neferabu, during the reign of Ramesses II, may have been a private building. ${ }^{4}$

\footnotetext{
${ }^{1}$ Helck, Materialien, 337-49; Bogoslovsky, VDI 1 (147), (1979), 3-23.

${ }^{2}$ It is unclear whether retired workmen or widows were entitled to remain within the community. Relatives may have been expected to provide suitable accommodation for widowed and divorced women.

${ }^{3}$ Pap. Bulaq X, vso. 4; cf. Janssen \& Pestman, JESHO 11 (1968), 160. Similarly a woman

Tawerethotepti was entitled to own an at-hut which was situated "next to the temple of Amenre" (O. DM 586, 5).

${ }^{4}$ O. Gardiner, 133.
} 
The workmen obviously spent much of their leisure time working on the construction, maintenance and improvement of their private buildings, in particular their tombs and associated chapels (xnw). However they also erected many different kinds of constructions both in the village, at the two royal worksites and even as far as the riverbank. ${ }^{5}$ We shall discuss below that the rights to these settlements, which were transferable, were occasionally the cause of an argument between relatives and colleagues as well.

\section{Dispute One}

A state of relationships is recorded on the recto of Papyrus Bulaq X. It has been assumed that the author of this text was Hay (V), son of Huy (VII)/ (IX). ${ }^{6}$ We are told that in addition to providing a burial place for his father Huynefer (IV)/Huy (VII)/ (IX) had also prepared a coffin for the burial of his mother, Tagemyt (I). Egyptian law made the unquestionable provision that "to the one who buries shall be given the property". ${ }^{7}$ Consequently since Huy (VII)/ (IX) alone had buried both his parents, their property fell to him by natural succession. However the remaining children of Tagemyt (I), Hay (V)'s uncles and aunts, were now declaring a right to the inheritance which they believed was their right.

This dispute was probably ended by the death of Huy (VII)/ (IX), some time before year 8 of Ramesses III. ${ }^{8}$ The last attestation known for a Huy, son of Huynefer, occurs in year 5, possibly during the reign of Ramesses III. ${ }^{9}$ The dispute is finally resolved in favour of Hay (V) by decree of the god Amenophis I before the qnbt court.

\section{Dispute Two}

A property dispute is recorded in Gardiner Ostracon 23. It has been suggested that it is a property dispute between Mose, the son of Anakhtu (IV), and Amenniutnakht, probably some time during the reign of Ramesses IX. ${ }^{10}$ At an oracular assembly certain properties are distributed, the text states: "One gave him the house of Telmont and likewise his xnw and his at-hut which is <in> the valley and his tomb. "One gave the house of Anakhtu and his xnw and his tomb and his at-hut which is in the Valley to the workman Mose" (11.5-8). The identity of the heir of Telmont's property is unclear, though McDowell proposes that it was the workman Amenniutnakht. ${ }^{11}$ Later Amenniutnakht swears that he will "not dispute any property of those belonging to Anakhtu, their (?) ${ }^{12}$ father" (11.9-10). Allam's proposal that the suffix "their" would

\footnotetext{
${ }^{5}$ For a discussion of the various types of private property owned by the workmen see Janssen \& Pestman, JESHO 11 (1968), $158 \mathrm{ff}$.

${ }^{6}$ Janssen \& Pestman, JESHO 11 (1968), 142.

${ }^{7}$ Pap. Bulaq X, rto. 10-11; cf. Janssen \& Pestman, ibid., 167-69.

${ }^{8}$ Cf. Janssen \& Pestman, ibid., 143.

${ }^{9}$ Pap. Greg, rto. A, 12.

${ }^{10}$ Allam, HOP, 154.

${ }^{11}$ McDowell, Jurisdiction, 123.

${ }^{12}$ Černý \& Gardiner, HO I, pl. 43: 4, read this pronoun as plural .w.
} 
have stood for "our" suggests the possibility of a dispute between two brothers over the inheritance of their father. ${ }^{13}$ Whilst there is evidence that Mose was a son of Anakhtu, the research has been unable to find a similar relationship for Amenniutnakht. ${ }^{14}$ The oath taken by Amenniutnakht is certainly indicating that there may have been some dispute over these properties in the past. Alternatively McDowell has suggested that this document is a record of the official transfer of state property to the two workmen, Mose and Amenniutnakht. ${ }^{15}$

\section{Dispute Three}

In year 27 of Ramesses III the workman Khaemwaset made the following appeal to Amenophis I the text states: "[Come] to me my Lord and judge between me and the workman Neferhotep. Shall one(?) ${ }^{16}$ take the at-hut ${ }^{17}$ of Baki, my (fore)-father, which is in the Great Tract, from the share of Sakhmet-nofret, O my great light?" The God walked backwards most emphatically. One said to him: "Should one give it to Khaemwaset?" The God agreed most [definitely]. Before: the chief workman Khons, the chief workman [An]hurkhawy and all the bearers. He [said to Iyer]nutef: "Do not enter the at-hut! ?"18 The facts of the case are obvious that Khaemwaset and Neferhotep were in dispute over the at-hut of Khaemwaset's ancestor, Baki. Černý's proposal that matters had come to its peak upon the death of the woman, Sakhmetnofret, cannot be established with any certain degree of certainty. ${ }^{19}$ In any case the law came down on the side of Khaemwaset. We are at a loss to explain exactly why Iyernutef was ordered not to intrude in the same at- hut. ${ }^{20}$

A second appeal describes how an unnamed person had erected a stela in this at hut, perhaps to establish a legal claim to this property. Demarée has implied that this person was Neferhotep. ${ }^{21}$ It is possible that Iyernutef had similarly interfered with Khaemwaset's property through whom his decision was to be relayed.

Demaree identified Khaemwaset as the son of Penamun, son of Baki. ${ }^{22}$ It is unlikely that a grandson of the foreman Baki (I) would have been active late in the reign of Ramesses III. Furthermore I am not aware of a Khaemwaset as a son of Penamun (II), son of Baki (I). ${ }^{23}$ However Khaemwaset may be identified with

\footnotetext{
${ }^{13}$ Allam, HOP, 154, n. 5.

${ }^{14}$ Bierbrier, CdE 59 (1984), 212, n. 2, following Gutgesell, Datierung, 308, certainly believes this to have been the case.

${ }^{15}$ McDowell, Jurisdiction, 99, 113, 119, 123.

${ }^{16}$ The reading iw.tw has been suggested by Demarée, in Gleanings, 102, note (f).

${ }^{17}$ Janssen \& Pestman, JESHO 11 (1968), 160, have shown that an at-hut, presumably a workman's dwelling, was different from the homes (pr) in the village proper.

${ }^{18}$ O. Petrie 21, rto.3-vso.4.

${ }^{19}$ Černý, in Parker, Oracles, 41; cf. Bedell, Criminal Law, 230. However Sakhmetnofret probably does occur as a feminine proper name.

${ }^{20}$ Helck, Materialien, 341, suggests that Iyernutef was the god's earthly intermediary through whom his decision was to be relayed.

${ }^{21}$ Demarée, in Gleanings, 104.

${ }^{22}$ Demarée, in Gleanings, 102, note (c); cf. McDowell. Jurisdiction, 119.

${ }^{23}$ Davies, Who's Who, 3.
} 
Khaemwaset (III), son of Penamun (IV), who was himself the son of Khaemwaset (I) and Taweretherti. Therefore if we associate Baki with the foreman Baki (I), Khaemwaset would have been a distant relative of him. Iyernutef is undoubtedly the same man as the "sculptor" Iyernutef (III). However the name of Neferhotep is too common to afford a affirmative identification.

\section{Dispute Four}

Similarly the relationship between the claimant and the defendants in the following dispute are unclear: "Year 1, 2nd month of Shomu, day 30. On this day the complaint by Isis against the workman Khaernope, the workman Khaemwaset and the workman Amennakht, saying: "Let the places (properties) of Panekhu[.. ], my husband, be given to me". It was consulted with the officials, and they said: "The woman is right! "The places of her husband were given to her. She was accepted (lit. "taken") because of him" ${ }^{24}$ It is possible that the three workmen were the sons of Panekhu[...], in which case they would have been his legal heirs. ${ }^{25}$ However, the decision of the officials in granting Isis ownership of the property does not support this argument. It has been suggested that Isis may have simply been awarded usufruct over these properties, ${ }^{26}$ though this seems unlikely. Alternatively Panekhu[..], being childless, may have a legal excuse by adopting his own wife as his sole heir, similar to events described in the Adoption papyrus. ${ }^{27}$ By these means Isis would have been allowed to inherit from her husband even to the detriment of his siblings, who in our case may have been the three workmen. Likewise it was possible for the husband to make a specific provision for his wife of part of his property should they happen to divorce. ${ }^{28}$ These arrangements may have been recorded on a separate document which has unfortunately not survived. A less likely solution is that the property of Panekhu[..] consisted of the joint property of this couple in which case Isis was entitled to onethird. ${ }^{29}$ Unfortunately I have been unable to find any familial connection between the three workmen. It has been suggested that Panekhu[.. ] may be identified with Panakht (III), son of Nakhtsu (I). ${ }^{30}$ However the names of the three workmen do not appear amongst the known members of the family of Nakhtsu (I). It may be justifiable to argue that the workmen had each taken illegal occupancy of separate properties following the death of Panckhu[..].

\footnotetext{
${ }^{24}$ O. DM 235.

${ }^{25}$ Janssen\& Pestman, JESHO11 (1968), 165; Théodoridès, RIDA 16 (1969), 173, n. 250.

${ }^{26}$ Théodoridès, RIDA 16 (1969), 173, n. 250.

${ }^{27}$ Gardiner, JEA 26 (1940), 23-29.

${ }^{28}$ Pestman, Marriage, 124-25.

${ }^{29}$ Janssen\& Pestman, JESHO11 (1968), 165.

${ }^{30}$ Davies, Workmen in the Deir el-Medina Community, 286-87.
} 


\section{Dispute Five}

Another property which was at the centre of a dispute was the "lower storehouse" of a lady called Iuner. ${ }^{31}$ Although this text has been discussed at length by Janssen and Pestman, ${ }^{32}$ The ostracon contains two cases which are probably related, in that they both involve the same storehouse. ${ }^{33}$ If further proof were needed, it is most probable that both episodes were written by the same hand. The first episode relates that the workman Nebsmen, the father of the author of the text, had supplied Iuner with a decorated coffin, in return for which he was to be given her "lower storehouse". Furthermore the right of this property succession was legitimised when Nebsmen performed the burial ceremony for Iuner. Unfortunately we are not told of the relationship between Iuner and Nebsmen, though it has been implied that she may have been his mother. ${ }^{34}$ It is apparent that the document represented the written legal rights to the property of the unnamed son on behalf of his siblings. However following Nebsmen's death Iuner's daughter, Wab(et), and the workman Huynefer lay claim to the storehouse. Allam has suggested that Huynefer was in fact the son of Nebsmen, ${ }^{35}$ whilst Théodorides believes Iuner to have been the second wife of Nebsmen and that Wab(et) was her daughter by a former marriage. ${ }^{36}$

The second part of the text records how Siwadjet (IV), having buried his mother Tanehsy, without the assistance of his siblings, was now laying claim to the said "storehouse" as his inheritance. A hypothetical format describing the relationships of the persons involved in Ostracon Petrie 16 is set out by Janssen and Pestman. ${ }^{37}$ However we shall now propose a slightly different theory. Nebsmen is probably the workman who is well-attested during the latter part of the 19th Dynasty and may even be related with the passing deputy Nebsmen (I). There is a slight, though weak, possibility that a Nebsmen, who is named in TT 216, was the "son of $<$ Si $>$ wadjet". ${ }^{38}$ If this were the case, this man may be identified with our Nebsmen, and it is possible that Iuner was therefore the wife of this Siwadjet. Consequently Siwadjet (IV) may have been one of the children of Nebsmen. However, it must be acknowledged that there is no definite evidence that Nebsmen was a son of Siwadjet. However it is possible that the second portion of the text was the basis for a counter-claim to the storehouse by Siwadjet (IV) by the fact that he alone had buried his mother, Tanehsy. Is it possible that the author of the first episode was the brother of Siwadjet (IV) and that their parents were Nebsmen and Tanehsy? We agree with Janssen and Pestman that

\footnotetext{
${ }^{31}$ O. Petrie 16 (Černý \& Gardiner, $H O$, pl. 21: 1).

${ }^{32}$ Janssen \& Pestman, JESHO 11 (1968), 153 ff.

${ }^{33}$ Janssen \& Pestman, JESHO 11 (1968), $157 \mathrm{ff}$.

${ }^{34}$ Janssen \& Pestman, op. cit., $155 \mathrm{ff}$.

${ }^{35}$ Allam, HOP, 232.

${ }^{36}$ Theodorides, RIDA 16 (1969), 141, n. 142.

${ }^{37}$ Janssen \& Pestman, op. cit., 155-57.

${ }^{38}$ PM I: 1, 313 at (6-8); Černý, Repertoire, 105; KRI 1115:8 9:6 -7; cf. O.D M 353, rto. 5.
} 
Wab(et) and Huynefer may well have been Nebsmen's siblings and that all three were the children of Iuner. ${ }^{39}$

It is interesting to note that on his fragmentary stela the "Servant of the Lord of the Two Lands in the Place of Truth" Siwajdet names his brother as Huynefer ${ }^{40}$, who could he have been named after his uncle?

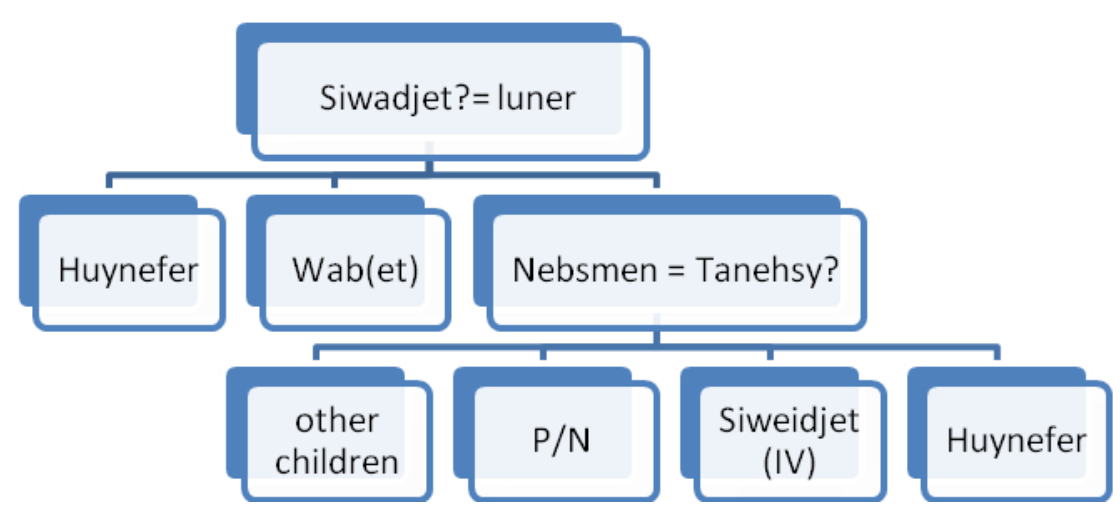

Alternatively a simpler solution would be to argue that the second part of the text formed the citation of a legal precedent, used by the son of Nebsmen in his attempt to legitimize his claim, and that of his siblings, to the storehouse. ${ }^{41}$ Indeed this agrees well with the concluding statement in vso. 4-6: "May my (=Nebsmen's son) Lord ensure that it (=storehouse) be shared with me because of them (=the other children of Nebsmen), for he (=Nebsmen/Siwadjet) did it for her (=Iuner/Tanehsy) when she was dead". Whatever the relationships of these individuals may have been, this text gives us another close insight into the problems of inheritance within the village and the likely arguments which could arise between members of the same family.

\section{Dispute Six}

The most interesting and perhaps the most widely documented property dispute that occurred at Deir el-Medina is the basis of three separate texts. ${ }^{42}$ The case begins in year 21 of Ramesses III, the 2 nd month of Shomu, day $1 .^{43}$ On that day an unidentified workman, presumably Amenemope, records that he had been allocated the tomb of his ancestor Hay by an oracular judgement. Nearly a year later an official investigation was opened to inspect possible illegal activity in the local necropolis. ${ }^{44}$ The shaft in

\footnotetext{
${ }^{39}$ Janssen\& Pestman, op. cit., 155.

${ }^{40}$ PM 1: 2, 734; Clére, BIFAO 28 (1929), 188-89: 8, 2: 8; KRI IV: 338.

${ }^{41}$ Rto. 6-vso. 4. Cf. Allam, HOP, 232; Gutgesell, Datierung, 414.

${ }^{42}$ O. BM 5624; O. Florence 2621; Pap. Berlin P. 10496.

${ }^{43}$ O. BM 5624, vso. 5; cf. Janssen, BiOr 32 (1975), 293. The sequence of events presented

below casts serious doubt on the accuracy of the commentaries of Blackman, JEA 12 (1926),

179-80, Bedell, Criminal Law, 265-66 and Allam, HOP, 45.

${ }^{44}$ Pap. Berlin P. 10496, rto. 1 ff; O. BM 5624, rto. 4 ff.
} 
the tomb of the workman Khaemnun was inspected and it was found that the shaft of Amenemope's tomb had been breached. It appears that this misbehaviour had been committed by Khaemnun, together with the "district-officer" Neferhotep, during the previous day. ${ }^{45}$ Amenemope was ordered to open the mouth of his tomb. On entering the tomb of Amenemope, an uninscribed coffin was found, though there was no further evidence of burial. The case ends with a confirmed statement, probably by Khaemnun, that he would not enter the tomb again. It seems likely that Khaemnun had secretly entered Amenemope's tomb by means of a subterranean shaft. It cannot be confirmed whether Khaemnun had committed any crime by this illegal entry, though Helck certainly believes that Khaemnun had removed the bodies of Amenemope's relatives from the tomb. ${ }^{46}$ It is, however, possible that Khaemnun had chanced to lay claim to the redundant tomb of Amenemope. However Amenemope's legal rights to this tomb, had already been established by the god Amenophis I a year earlier. Unfortunately I have not been able to locate the tombs of the two individuals who can now be identified as Khaemnun (I) and most probably Amenemope (X). A fragment of a stela of the Servant in the Place of Truth Khaemnun (I) and his wife [Nau]nakhte (I) was recovered from the court of $\mathrm{TT} 1,{ }^{47}$ which suggests a possible approximate findspot for their tomb. It is possible that the famous scribe may have been buried in TT 1126 which lies in the close vicinity of TT $1 .^{48}$

Two years after this incident, in year 24 of Ramesses III, the 1st month of Shomu, day 30, the workmen Amenemope, son of Meryre and Wennefer, son of Penamun, appeared before the local qnbt-court. ${ }^{49}$ It is apparently Amenemope who makes the following claim, the text states: "The xnw of Amenmose and his tomb are in my possession, whilst the commissions for Baki (I) are in his possession also. (However) he has thrown out my mistress (inwt) from the tomb of my father" (vso. 9-11). Wennefer was made to swear never again to enter Amenemope's tomb. It can be assumed that Amenemope, son of Meryre, is to be identified with the Amenemope (X) who was involved in the earlier dispute. ${ }^{50}$ Wennefer, son of Penamun is probably identified with Wennefer (III), a direct descendant of the foreman Baki (I) whose tomb was TT 298. ${ }^{51}$ Ameneinope (X)'s complaint was that Wennefer (III) had removed the

\footnotetext{
${ }^{45}$ O. BM 5624, rto. 1-4.

${ }^{46}$ Helck, Materialien, 3,48. Lorton, JESHO 20 (1977), 40, suggests that certain goods had been stolen from the tomb.

${ }^{47}$ Bruyere, Rapport (1928), II, 135.

${ }^{48}$ PM 1: 2, 687; Bruyere, Rapport (1927), 27. However, monuments of Qenhirkhopshef (I) were found in other sectors of the necropolis. A table of offerings of Qenhirkhopshef (I), found in TT 216, probably came from TT 7 of the scribe Ramose (I) (Bruyere, Rapport (1923- 24), 46); a fragment of a limestone stela with the name of Qenhirkhopshef was found to the west of TT 8 (Bruyere, Rapport (1926), 14); between pits 1039 and 1040 there was found fragments of a libation table with the name of Qenhirkhopshef, possibly as a royal scribe in the Place of Truth (Bruyere, Rapport (1924-25), 48-49); in TT 1335, just to the south of TT 1334, fragments of frescos with the names of Huy and the scribe Qenhirkhopshef, which may have originated from TT 1336, were found. (Bruyere, Rapport(1933-34), 73, fig. 35 , pl. II).

${ }^{49}$ Pap. Berlin P. 10496, vso. 6 ff.

${ }^{50} \mathrm{Cf}$. Allam, HOP, 280; McDowell, Jurisdiction, 162.

${ }^{51}$ Davies, Who's Who, 3.
} 
body of his "mistress", either his wife or his mother, Tarekhanu (II), from his tomb, perhaps in an attempt to use it as his own. Amenemope (X) was certainly having very little fortune with his newly acquired tomb. Within a matter of years his inheritance had already come under attack by two of his deceiving colleagues.

\section{Dispute Seven}

It is hardly surprising that we meet the Merysekhmet (III) at the centre of a conflict over the possession of a "chapel" (xnw). ${ }^{52}$ The workman Qenna (VI), son of Siwadjet, besought Amenophis I with the source of his discontent, the text states:

"Come to me my Lord, for it was I who (re-)built the xnw of the workman Pakhuru, when it had collapsed. Now see the workman Merysekhmet, son of Menna, has not allowed me to be able to sit ${ }^{53}$ in it, saying - "It was (7) the god who said to me(=M) - share it with him (lit. "you"=Q)!". But he (=M) did not (re-)build it with me!".54

Having gained the support of the important sS n pA xr Harshire (I), who repeated the appeal to the god, the oracular judgement came down on the side of Qenna: "Give the xnw again to Qenna, its owner! It is his by the command of Pharaoh, and no man shall (be able to) divide it with him". ${ }^{55}$ It is interesting that Merysekhmet (III)'s lack of moral principles knew no boundaries. His statement that the god had permitted him to share the "chapel" with Qenna was an obvious trick to take in an unfortunate, and perhaps powerless, opponent. Interestingly the record states that this event took place at the tomb of the foreman Qaha (TT 360) which possibly neighboured the "chapel" of Qenna. ${ }^{56}$

\section{Dispute Eight}

A most unusual real estate argument involved the right of access to a storehouse of Kel (Keno) between the workmen Hay, son of Huy, and Pentaweret in year 13 of Ramesses III. This is probably the same Hay (V), son of Huy (VII)/ (IX), who made provision for his children from the property of his father five years previously. ${ }^{57}$ It is possible that Huy (VII)/(IX) is to be identified with Huy (VI), son of Huynefer (II), in which case he was a nephew of the foreman Qaha (I). Several men named Kel are attested amongst this family, e.g. Kel (I), brother-in-law of Qaha (I); Kel (II), son of Anhurkhawy (I); Kel (IV), the son of Huy. It is possible that Kel (IV) was the son of Huy (VII)/ (IX) and brother to Hay (V), or that he was the son of Huy (V), son of Anhurkhawy (I). ${ }^{58}$ Unfortunately there is no confirmed evidence on which to base a direct relationship between Hay and Kel. Nevertheless it is probable that Hay derived his rights of access to the storehouse of Kel through a family connection. Furthermore

\footnotetext{
${ }^{52}$ O. BM 5625 (Blackman, JEA 12 (1926), 181-83, pls. 35-36, 41; KRI VI: 25-53).

${ }^{53}$ This interpretation of Hms was suggested by Janssen \& Postman, JESHO 11 (1968), 162.

${ }^{54}$ Rto. 3-8.

${ }^{55}$ Vso. 3-5.

${ }^{56}$ Janssen, in Gleanings, 119.

${ }^{57}$ Pap. Bulaq X, verso; cf. Janssen \& Pestman, JESHO 11 (1968), 167-69.

${ }^{58}$ Davies, Workmen in the Deir el-Medina Community, 23.
} 
it is possible, though not proven, that the storehouse in question was the same one which had formerly been in the hands of Kel (II), son of the foreman Anhurkhawy(I). ${ }^{59}$ However we learn that Kel (II) had died by the reign of Amenmesses, ${ }^{60}$ and that the storehouse had subsequently become the property of his brother Hay (IV). But when Hay (IV) was promoted to the foremanship in about year 1 of Amenmesses, the property was granted to another brother, Qaha (II). However by year 11 of Ramesses III the storehouse may have ended up in the hands of Hay (IV)'s son, Anhurkhawy (II) ${ }^{61}$, it is at this time that the workman Amenemope, son of Meryre, challenged Anhurkhawy (II)'s rights to the storehouse at the qnbt-court. ${ }^{62}$

However, Amenemope's father came forward to counter his son's assertion as an obvious fabrication, and to be a witness to Anhurkhawy (II)'s legal ownership of the said storehouse. Amenemope took his complaint before the local oracle three days later. However, the god merely confirmed the ruling of the qubt-court. There follows a badly broken passage in which "Neferhotep, his brother" is mentioned together with an Isbt-hut(?) ${ }^{63}$ There are also traces of "this storehouse" and the naming of "the god" and "Amenemope". It is impossible to make any sense of this data. However, we do know that Neferhotep (XI) was a brother of Amenemope (X), son of Meryre. It is therefore not unlikely that Neferhotep (XI) was involved, perhaps in conspiracy with Amenemope. The text continues by recording the oath of an unidentified person, the text states: "I shall not contest th[is storehouse] and no one of my fa[mily] shall contest it" (rto. 11). Unfortunately we are not able to determine the identity of the speaker, though it could equally have been the father, Meryre, or one of his sons.

Returning to the former dispute we learn that access to the storehouse was granted by a committee of village dignitaries to Hay, possibly to the chagrin of Pentaweret. It is believable that Pentaweret had lodged a dispute with the authorities concerning Hay's rights to the access-way. Černý has argued that the storehouse was actually granted to Pentaweret. ${ }^{64}$ Nearly two years later, ${ }^{65}$ Pentaweret appealed to Amenophis I protesting that he was still unwilling to give up "this path of entry or exit to $\mathrm{Ha}[\mathrm{y}]$ "66 Once more his complaint was invalidated by the god and Hay's rights were again maintained. ${ }^{67}$

Apparently on the same day the workman Hay asked the god's permission for the lady Hutiyi to remove some beams from a door which belonged to her. ${ }^{68}$ McDowell seems to think that the two episodes were connected ${ }^{69}$ However Allam's claim that

\footnotetext{
${ }^{59}$ O. Geneva MAH 12550, rto. 2.

${ }^{60}$ Davies, Workmen in the Deir el-Medina Community, 23.

${ }^{61}$ There is, however, no direct evidence to refute the argument that the storehouse may still belong to Hay (IV), and that Anhurkhawy (II) was appearing in court, with Amenemope, as his father's representative.

${ }^{62}$ O. Geneva MAH 12550, rto. 5-6.

${ }^{63}$ O. Geneva MAH 12550, rto. 9.

${ }^{64}$ Černý, BIFAO 30 (1931), 495; cf. McDowell, Jurisdiction, 120

${ }^{65}$ Not ten months as calculated by Allam, HOP, 61 .

${ }^{66}$ O. CGC 25555, rto. 5-6.

${ }^{67}$ For an alternative interpretation see Černý, BIFAO 30 (1931), 495.

${ }^{68}$ O. CGC 25555, vso. 1-3.

${ }^{69}$ McDowell, Jurisdiction, 120; cf. Černý, BIFAO 30 (1931), 495.
} 
Hay opposed Hutiyi's rights to this property is unconfirmed. ${ }^{70}$ It is possible that Hutiyi is to be linked to Hutiyi (I), daughter/daughter-in-law of the future deputy Hay (VII), son of Amennakht (X). Therefore the workman Hay may possibly be identified as Hay (VII), or was in some way a relative of Hutiyi.

\section{References}

- Allam, S., Hieratische Ostraka und Papyri aus der Ramessidenzeit, (text \& plates vols.), Tübingen, 1973.

- Bedell, E. D., Criminal Law in the Egyptian Ramesside Period, (Unpublished dissertation). Brandeis, 1973.

- Bierbrier, M. L., "Notes de Prosopographie Thebaine. Troisicme scrie", CdE 59 (1984), pp. 199-222.

- Blackman, A. M., "Oracles in Ancient Egypt", JEA 12 (1926), pp. 176-85.

- Bogoslovsky, E. S., "Property and Ex-Officio Possessions in Ancient Egypt (Based on material from Deir el-Medinéh)", VD 1 (147), (1979), pp. 3-23.

- Bruyére, B., Rapport sur les fouilles de Deir el Mèdineh, FIFAO, Cairo, 1922-1951.

- Bruyére , B., La Tombe No. 1 de Sen-nedjem a Deir el Medineh, MIFAO 88, Cairo, 1959.

- Clére, J. J., "Monuments inedites des serviteurs dans la Place de Write”, BIFAO 28 (1929), pp.173-201.

- Černý, J. \& A. H. Gardiner, Hieratic Ostraca I, Oxford, 1957.

- Černý, J., "Une Expression Designant la Reponse N6gative d'un Oracle”, BIFAO 30 (1931), pp. 491-96.

- Černý, J., Catalogue general des antiquites egyptiennes du Musee de Caire, Ostraca hieratiques. Nos. 25501-25832, Cairo, 1935.

- Černý, J. \& G. Posener (ed.), Papyrus hieratiques de Deir el-Medineh I [Nos. I-XVIII, Cairo, 1978.

- Černý , J., "Egyptian Oracles", in R. A. Parker, A Saite Oracle Papyrus from Thebes in the Brooklyn Museum, Providence, 1962, pp. 35-48.

- Černý, J., B. Bruyére \& J. J. Clére, Repertoire onomastiquetic Deir el-Medinéh, DFIFAO 12, Cairo, 1949.

- Daressy, G., Catalogue general des antiquites egyptiennes du Musee du Caire, Cairo, 1901.

- Davies, B.G., Who's Who at Deir el-Medinéh: a prosopographic study of the royal workmen's community, Leiden, 1999.

- Davies, B.G., Genealogies and Personality Characteristics of the Workmen in the Deir el-Medinéh Community during the Ramesside Period, (unpublished dissertation), Liverpool, 1996.

- Demarée, R.J., Ramesside Ostraca, London, 2002.

- Demarée, R. J. \& Janssen, J. J. (eds.), Gleanings from Deir el-Medinéh, Leiden, 1982.

- Eyre, C. J., Employment and Labour Relations in the Theban Necropolis in the Ramesside Period (unpublished dissertation), Oxford, 1980.

- Eyre, C. J., “The Use of Data from Deir el-Medinéh”, BiOr 44 (1987), pp. 21-32.

- Eyre, C. J., "Work and the Organisation of Work in the New Kingdom", in M. A. Powell (ed.), Labor in the Near East, New Haven, Connecticut, 1987, pp. 167-221.

- Gardiner, A. H., “Adoption Extraordinary”, JEA 26 (1940), pp. 23-29.

- Gutgesell, M., Die Datierung der Ostraka und Papyri aus Deir el-Medineh und ihre ökonomische Interpretation, HAB 18-19, Hildesheim, 1983.

- Helck, H. W., Materialien zur Wirtschaftsgeschichte des Neuen Reiches, parts 1-6, Wiesbaden, 1961-1969.

- Janssen, J. J. \& P. W. Postman, "Burial and Inheritance in the Community of the Necropolis Workmen at Thebes", JESHO 11, (1968), pp. 137-170.

- Janssen, J. J., Hieratic Papyri in the British Museum VI: Late Ramesside Letters and Communications, London, 1991.

- Janssen, J. J., "The Rules of Legal Proceeding in the Community of Necropolis Workmen at Deir elMedinéh", BiOr 32 (1975), pp. 291-296.

- Kitchen, K. A., Ramesside Inscriptions, Historical and Biographical, vol. I-VII, Oxford, 1968-1990.

- Kitchen, K. A., Ramesside Inscriptions Translated and Annotated I, Oxford, 1993.

- Kitchen, K. A., Ramesside Inscriptions Translated and Annotated: Notes and Comments I, Oxford, 1993.

- Lorton, D., "The Treatment of Criminals in Ancient Egypt", JESHO 20 (1977), pp. 2-64.

- McDowell, A. G., Jurisdiction in the Workmen's Community of Deir el-Medinéh, Leiden, 1990.

- Posener, G., Catalogue des ostraca hieratiques litteraires de Deir el-Medineh, DFIFAO 1, 18 \& 20, 19341980.

- Chabas, F. J., Les papyrus hiératiques de Berlin, Paris 1863.

- Pestman, P. W., Marriage and Matrimonial Property in Ancient Egypt, Leiden, 1961.

\footnotetext{
${ }^{70}$ Allam, $H O P, 61$.
} 
- Porter, B. \& R. L. B. Moss, Topographical Bibliography of Ancient Egyptian Hieroglyphic Texts, Reliefs and Paintings, I-VII, Oxford, 1927 ff.; 2nd ed., J. Malek, Oxford, 1960 ff.

- Posener, G., Catalogue des ostraca hieratiques litteraires de Deir el-Medineh, DFIFAO 1, 18 \& 20, $1934-$ 1980.

- Sauneron, S., Catalogue des ostraca hiératiques non littéraires de Deir el Médineh [VI] (Nos. 560-623), Le Caire, 1959.

- Shinichi, A., "Dating and Understanding of the Papyrus Greg", Bulletin Of the Society for Near Eastern Studies in Japan, 38(1995) 1, pp. 16-32.

- Spiegelberg, W. \& Quibell, J. E., Hieratic Ostraka and Papyri found by J. E. Quibell in the Ramesseum, 1895-96, London, 1898.

- Theodorides, A., "Les ouvriers - <magistrats> on Égypte ä l'epoque ramesside”, RIDA 16 (1969), pp. 10388.

- Tosi, M. \& A. Roccati, Stele e altre epigrafi di Deir el Medinéh n. 50001-50262, Cat. Mus. Eg.Tor. Ser. 2Collezioni, vol. 1, Turin, 1972.

- Ward, W. A., "Some Foreign Personal Names and Loan-Words from the Deir el-Medineh Ostraca", in A. Leonard \& B. B. Williams (eds.), Essays in Ancient Civilization Presented to Helene J. Kantor, Chicago, 1989, pp. 287-303. 